\title{
The Process of Transformation in the Modern Crimea
}

\author{
Irina A. Khalii* \\ Institute of Sociology \\ of the Russian Academy of Sciences \\ 24/35, Krzhizhanovsky Str., Building 5, Moscow, 117218, Russia
}

Received 10.11.2015, received in revised form 15.02.2016, accepted 25.03.2016

The current events in Crimea represent a clear transit from one political and cultural mode to another. It does not include a radical economic element, i.e. a move toward market relations, since this line has already been taken and implemented to some degree in the analyzed societies. As the logic goes, a new transit is not so extreme, comparing with the transit from socialism towards capitalism. Nevertheless, it has also become a cause for so called "cultural trauma" described by P. Shtompka. Then, there is a vital question of how to cope with it. This transit is the core focus of our research. The analysis is based on the informal observation over the general mood in the Crimean society during the postSoviet periods and on the results of experiments carried out by the department for social and cultural development in Russia from August to September, 2015. The research is done on the one hand with the means of qualitative methods, i.e. using in-depth interviews with the officials and representatives of healthcare organizations, cultural and educational institutions as well as with the locals from five cities (84 interviews in total); and, on the other - through the method of focus-groups with students studying in 3 different universities. A special attention should be paid to the fact that this research has not been conducted in the Crimean Tatar community. It has been described that transformational processes are being performed, and the idea of their implementation is possessed by the biggest part of the Crimeans. It has also been demonstrated that the transformation is based on a sustainable constancy of the Republic of Crimea's residents in their focus on Russia, together with their economic activity which also has only slightly changed in the course of time. Within the analysis of a successful merge between Crimea and Russia, some essential requirements as well as their presence in the modern Crimean society have been defined. In particular, they include sufficiency of economic and human resources, civil accord between social elites, governmental retention of the social control, pro-active measures on heated social and armed conflicts. As the research has shown, the process of joining to Russia has a future, since today's young generation, and students in particular, are sure in their "Crimean position": they study in this region and have fixed plans for their further life there.

Keywords: transformation, cultural trauma, political and cultural mode, Crimean society, local communities, joining to Russia.

DOI: 10.17516/1997-1370-2016-9-4-978-985.

Research area: sociology.

(c) Siberian Federal University. All rights reserved

* Corresponding author E-mail address: illaio@yandex.ru 
The current situation in Crimea is an obvious transit form one political and cultural practice to another. This way doesn't include any radical economic element, i.e. a move toward market relations, since that target has already been accepted and performed to some degree within the addressed communities. In this way, one would think, a new transit is not so drastic in comparison with a shift from socialism to capitalism. Still, it brings to life a "cultural trauma" mentioned by P. Shtompka. Then, there is a necessity to cope with it. Such a transfer is the main focus of the current research.

Theanalysis is based on informal examination of the public mood in Crimea of the post-Soviet period as well as on the results of field researches carried out in August and September, 2015 by the research department for regional socio-cultural development in Russia. The work has been done through a number of qualitative methods, such as in-depth interviews with officials, educational, cultural and healthcare institutions, and with locals and residents of five Crimean cities ( 84 interviews in total); and focus-group with thirdyear students studying in 3 different universities. It worth mentioning, that this research has not been conducted among the Crimean Tatar society. The purpose of this analysis is to show those socio-cultural lines in the Crimean society and in some local communities, which have become a ground for their efforts in accession to Russia.

\section{Reasons and driving forces of the transit}

The issue concerning the transit in Crimea mainly consists not in difficulties of shift towards market economy. Even during a similar transition in the end of $80 \mathrm{~s}$ and the beginning of $90 \mathrm{~s}$ a crucial change for Crimeans was the introduction of market economy - a precisely harmless measure, since nearly the whole Soviet period the locals were involved in "private" in the "touristic industry" (these words are written with quotation marks, since it definitely was not a traditional or legal entrepreneurship, as well as it can hardly be called "tourism"). Still, they turned out to be much impressionable to another transformation, i.e. joining to the other state, country and society. Obviously, it took some time to realize this fact, but all that time until 2013 Crimea had to feel like a territory forgotten by the national governmentthe fact expressed not so much within political, but economic domain (the survey conducted in this area speaks about their residents' dissatisfaction on the absence of economic policy concerning this region).

Still, as it was shown during the period of Euromaidan and after, it also had been not the main issue for the Crimeans. At that time to many people's surprise the situation in socio-cultural sector was radicalizing. Slogans (related to national identification, culture and language; the focus on integration with the EU; and especially a break in relations with Russia up to confrontation) mostly provoked a deep disapproval from the locals. According to a respondent's story, in his family one brother says that he is a Russian and the other one claims to be a Ukrainian. In this case, it is the bottom line of the "cultural trauma".

This trauma lies even in the fact that the society (even though the majority has not accepted the modern socio-cultural and political goals) has ended up in an unequal split. This research has indicated that such a separation always existed, although quite often implicitly. In the very beginning (i.e. in the $90 \mathrm{~s}$ ) the greater part of Crimea's population included former citizens of the Soviet Union - those who were highly sensitive for the death of the country. As time passed, a new generation has been brought up young people who spent their lives in Ukraine. That generation finished Ukrainian schools and then, as a rule, continued studying in other regions of that country with the following residence there. 
It formed a considerable social group which accepted Ukrainian socio-cultural environment. The most pronounced example is a story told us by the director of a museum: "My daughter was absolutely sure that one can live only in Ukraine. Lost in drinking and ruined Russia was entirely unacceptable, and we should not try to merge in that country. She was so much persuaded of the devastation in Russia that refused to believe even in preservation of historical monuments, like St. Basil's Cathedral. Nothing could talk her around. We had to go on excursion to Moscow together, since we really started to worry about her views. It took quite a long time in our family to somehow thaw her attitudes towards the joining”.

Still, by the year of 2013 even this group was not so numerous and sustainable (it seems to be, that if we had extra decade, and Ukrainization of Crimea's locals would have been completed). The research of 2015 showed the very few people who openly behaved against the merge of Crimea into the Russian Federation.

Firstly, almost no people left their place of residence, i.e. moved in Ukraine. Besides, very few youngsters entered Ukrainian universities during the post-Euromaidan period, and what is more, their choice was made deliberately. Such cases were mentioned in stories of our respondents from secondary schools, music schools and universities, as well as from institutes of extended education (everyone said about one or two of such cases).

The majority of those people, who was dissatisfied with the exit from Ukraine, noted an inescapable situation: "The demands made by the Ukrainian government and especially by leaders of the Maidan-movement, made it clear, that we had no other choice".

Undoubtedly, most significantly this situation impacted on the youth (particularly, on school children). Their world view, socio-cultural ideas, perception of the history and attitudes to the contemporary Russia were built in the climate of Ukraine. They are still not considered to be permanent bearers due to their age, but their change in today's world is a highly complex and painful procedure.

The biggest part of adults (aged 30 and older) in different ways express their views on the necessity to join Russia, but nearly all the opinions are based on the comprehension that they are for many reasons a part of the Russian society. Firstly, many of them are originally Russians, who moved to Crimea either in childhood or by themselves relatively not so long ago. Secondly, almost all local population are the Russian language speakers, traditions and culturebearers. Thirdly, many of respondents claimed that they flatly refused to recognize Russia as an enemy: "I became an ardent supporter of joining to Russia when in Kiev public documents declared that Russia was our enemy". The larger part of the population (particularly, women) was frightened by the threat of violence from radicals (memories of our respondents from Feodosiya): "Once we had heard that the Right Sector was coming to us, we took up arms of what just we had at that moment - form stick to pitchforks and ran out to the railway station. The train with the Right Sector activists arrived; they saw us and then, even without getting out of the train, drove away. We were scared, but that was our victory". Fifthly, Kiev's concerns were raised by plans to establish NATO elements in the territory of the peninsula even before Ukraine would enter this organization: "One of NATO's units came to our town. Soldiers were accommodated in hotels. We were confronted with a question: How would we fight? It became quite spontaneously, that the whole town started to hold protests, mass unrests with anti-war and anti-NATO slogans within several days. They saw it and went away. Everything passed quite peacefully". Moreover, many cultural institutions felt slighted neglected: 
under the Ukrainization, lack of money, absence of even moral and legislative support (this fact was especially emphasized by the staff of national territories under special protection and museums, related to the Russian culture, i.e. memorial museums of Russian writers). The next reason for dissatisfaction of Crimea's population was politically dictated: during different periods of time "varangians" - from Donetsk, Dnepropetrovsk and Kiev - dominated in Ukrainian executive authorities at all levels. We have already observed the same phenomenon in researches dedicated to the analysis of the European part of Russia and that time we have noted its provocative influence on social tension [Khalii 2014].

Thus, the bottom line of the first modification in Crimea proves the statement made by $\mathrm{R}$. Darendorf, that a post-state necessarily includes a conflict between the influence of original traditions and denial of them by people [Darendorf 1990]. Still, they turned to be so dominant, that now have lead to a new process of transformation. This transformation, in its turn, seems to be a sequence of the "dynamic chaos" - the title of the theory by I. Prigozhin, based on the idea that unexpected events can become a turning point in the following dynamics of the whole social, political and economic situation [Prigozhin 1986]. The case of Crimea has brought us to say about the prevalence of decision- making in the way "as situations demand", or "instrumental activism" as it is called in scientific researches [Genov 2000].

\section{A chance for the successful modern transformation}

In our consideration of a probable successful accession of Crimea to Russia we will rest on the conditions proposed by N. Naumova [Naumova 1999] which are necessary for the modernization of a society, since modernization means a change as well as the transformation in the context of this analysis. She emphasizes the following five terms: a) sufficiency of economic and human resources; b) civil accord between social elites; c) governmental retention of the social control, pro-active measures on heated social and armed conflicts; d) rapid growth in the number of middle-class members; and e) nationwide mobilization idea. Nevertheless, if for a successful modernization all the five conditions are important, then, obviously, for an effective merge of Crimea into Russia only the first three terms are crucial, since the others have not been formed yet in the host party (e.g. for the analysis of the readiness condition of the Russian society for modernization refer to [Tikhonova 2011]). Thus, let's focus only on the first three mentioned cases.

It is hard to speak about the sufficiency of economic resources. Undoubtedly, the situation has just got worse. To already low standards of well-being and economic situation in the republic, Ukraine's activity has been added, which enforces negative effects, i.e. water exclusion, cut off power supply resources (up to the distraction of ELT), road and railroad blocks not only with Ukraine, but also with Russia. Completely empty railway stations in Crimea, which once worked in the most exhausting way, impose distressing feelings. Consequently, it's hard to imagine, how the Crimeans passed 2014, when the tourist traffic completely stopped. Still, they did it, and now they even don't talk about how hard it was that time. Finally, sanctions have emerged yet unsolved problem of financial traffic via the core banking system, so that it compounds the living of not only local business, but of tourists as well.

Russia has done a lot, but the problems caused by some external reasons, are arising time and time again. A solution for the main problem on communication with the continent lies in the bridge construction over the Kerch Strait. But for 
the population it is hard to understand and accept the fact that almost the whole economic support from Russia at the present time is aimed at this very measure. As the result, others spheres of the population's living activities has been suffered from non-sufficient money means. Sometimes our respondents mentioned something of such dissatisfaction in their replies: residents of the Crimea hoped that they would instantly get better life, but that did not appear to be true. Thus, sometimes their replies were deeply aggressive: "If we continue in the same way, you'll meet a "Crimean autumn".

Here we'll turn to the analysis of human resources. During the very process of joining to Russia, Crimea's residents mainly felt euphoria, but having passed a lean year of 2014, people could get tired of waiting and hoping, if they would not be engaged into an active construction of their own lives. In fact, they are - they do the same thing as always - they take in tourists, since there are no other spheres for economic development. Perhaps, the only thing being brought to life again in the economic is the agricultural sector, both on the private and business-structure levels. The year of 2015 turned out to be quite friendly in terms of the weather, so people managed to nurture and gather a good harvest, corps, fruits and vegetables. In the framework of Western sanctions against Russia this may well play a crucial role in the development of the Crimea, though the problem still lies in logistics and goods transportation.

The same year was much softer towards the touristic sphere, although the level before Maidan has not been achieved and, apparently, won't be without additional governmental efforts, since they will "reject" Ukrainian tourists for whom Crimea was almost as a dacha - financially available, geographically near and belonged to them officially. Today the very few people leave Ukraine.
The situation with socio-economic state of the population is tough and thus raises fears. In this context, many things will depend on the activity of Crimean authorities at all levels (this is the second term, or the civil accord between social elites) and on their interrelationship not only with each other, but with the whole society as well. Within the interview in many locations of the Crimean public authorities have spoken about a necessity to constantly communicate with the population in order to make both views and actions of the federal and Crimean governments more clear. This requirement has been regularly called for by the Vice-Governor at First Crimean TV-channel.

At the stage of merging into Russia, officials from different power structures were a long way off the accord. Some people went to Ukraine that moment, others were in a hospital, some people just held back from any activity. It must be admitted, that in the most cases it was the position of the population that played a driving core part in the process of joining. Still, there were persons among civil servants, who without any doubts took the side of the society in those cases, when it actively expressed their views; or the side of activists, i.e. campaigners for joining to Russia, when the society was not so much interested, and in doing so, kept themselves away from what was happening and tried to hold the "dark days" off. Thus, according to the replies under the first case, "the population had had to hold a number of protests against the Administration's walls before the Mayor had to accept the national movement". The second case is described within the interview by one of actual Mayors, who was a deputy at that time: "I stayed in the administration building alone, when the whole town was waiting for the arrival of Ukrainian radicals, and the Mayor had got ill and checked into the hospital. It was really frightening". 
Finally, the last term of the successful Crimea's joining to Russia and its adaptation to the Russian living rules and policy is the governmental retention of the social control, which has been implemented by civil activists including authorities, their branches and some institutes such as the Supreme Soviet of Crimea. Undoubtedly, a steadying role was played by the Russian army, deployed in the territory of Crimea. Its active efforts were not mentioned in the responds, but all the interviewers were sure that it had become a guarantor for the absence of armed conflicts: "They did not have to interfere, but their presence in its turn soothed the situation. But for them, there would be much blood".

The responsibility for pro-active measures on social conflicts as a part of the successful transit lies mainly on the government, and on local branches of the Russian parliamentary political parties and civil society organizations, even probably in many respects on the last-named structures, including highly important national communities in this multi-national territory.

The Crimean Tatars, who have been ready to defend their interest within the recent 25 years, can be a potential trigger for the social tension (that is why they have some problems with the Majlis). A breeding ground for social conflicts can be formed by insufficient activity of the administration and authorities as well as a low level of the social self-management.

\section{Conclusion}

As we can conclude, the transformation is being performed, and the initiative of its implementation belongs to the biggest part of the Crimeans. Obviously, it is based on the durable self-consistency of the Republic of Crimea's residents in their focus on Russia; and on their economic behavior that also has only slightly changed over decades.

This analysis has shown that this ground has the future, since young people, students in particular, are solid for "Crimean position", i.e. they study there and will try to stay in this region for the whole life. When asked "why do they participate in the referendum?" the larger part of them answers this is the way they are brought up. We dare add that the general mood of people was one and the same, though of course, our young respondents did not realize it.

The further scenario depends primarily on those people, who control this process today, and on those, who will control in tomorrow. It is a mega-issue for different vector of the government's and society's worldviews to be tied up. To maintain this goal, the society itself should take an active stand and stop following a "passive strategy".

It seems to us that things can be contributed in this sphere by social scientists within this region. Actually, according to disputes shown on Krym-TV, they really are. Though, they are mainly related to political sciences, but still it is highly important today to comprehend social processes and perspectives of their development. Thus, Crimean sociologists have a good scope for the scientific work and enlightenment activity.

\section{References}

Darendorf, R. (1990). Reflection on the Revolution in Europe. London: Chatto and Windus.

Genov, N. (2000). Transition to Democracy and Nation-state in Eastern Europe, In The Analysis of the International Institute of Sociology (7).

Khalii, I.A. (2014). Kommunikatsiia vlast - obshchestvo: stala li sistema upravleniia otkrytoi? [The communication "power - society": has the system of administration become transparent?]. 
Modernizatsiia otechestvennoi sistemy upravleniia: analiz tendencii i prognoz razvitiia: materialy Vserossiiskoi nauchno-prakticheskoi konferentsii i XII-XIII Dridzevskikh chtenii [Proc. All-Russian Research-to-Practice Conf. "Modernization of the national system of management: analysis of tendencies and forecast of development" and the 12-13 Dridzevskii Readings]. Moscow, 227-231.

Naumova, N.F. (1999). Retsidiviruiuschaia modernizatsiia $v$ Rossii: beda, vina ili resurs chelovechestva [Recidivous modernization in Russia: a problem, fault or resource for the humanity]. Moscow: Editorial, $176 \mathrm{p}$.

Prigozhin, I., Stengers, I. (1986). Poriadok iz khaosa: Novii dialog cheloveka s prirodoi [The order out of chaos: a new dialog between men and the nature]. Moscow: Progress, $432 \mathrm{p}$.

Shtompka, P. (2001). Kulturnaia travma v postkommunisticheskom obshhestve [Cultural trauma in the post-Communist society], In Soysiologicheskie issledovaniia [Sociological Studies] 2, 3-12.

Shtompka, P. (2001). Sotsialnoe izmenenie kak travma [Social change as a trauma], In Sotsiologicheskie issledovaniia [Sociological Studies] 1, 6-17.

Tikhonova, N. E. (2011). Sotsialnaia modernizatsiia i perspektivy kulturnoi dinamiki v Rossii [Social modernization and visions on the cultural dynamics in Russia], In Rossia reformiruiushhaiasia: Ezhegodnik-2011 [Russia under reforms: Annals - 2011] 10, 110-126. 


\title{
Трансформационный процесс
}

\section{в современном Крыму}

И.А. Халий

Институт соииологии Российской академии наук Россия, 117218, Москва, ул. Кржижановского, 24/35, 5

\begin{abstract}
Происходящее ныне в Крыму есть очевидный транзит - от одного политического и культурного уклада к другому. Этот транзит не содержит в себе радикальной экономической составляющей - перехода к рыночным отношениям, поскольку такая установка уже воспринята и в какой-то степени реализована в рассматриваемых сообществах. В связи с этим новый транзит, казалось бы, не столь радикален, сколь транзит от сочиализма к капитализму. Однако, очевидно, и он вызывает к жизни «культурную травму, о которой писал П. Штомпка. Возникает необходимость её преодоления. Этот транзит и находится в фокусе данной статьи. Анализ основан на неформальном наблюдении за настроениями крымского общества в постсоветские годы и на результатах полевых исследований, осуществленных сектором по изучению соииокультурного развития регионов России в августе-сентябре 2015 2. Работа осуществлялась качественными методами: в виде глубинных интервью с представителями власти, образовательныхимедииискихорганизаций, учрежденийкультуры, а также с местными жителями в пяти городах Крыма (всего 84 интервью), а также в форме фокус-групп со студентами вузов (3 единиць). Следует особо отметить, что исследование не проводилось в крымско-татарском сообществе. Показано, что трансформационные процессы осуществляются и инициатива их реализации принадлежит большей части крымского общества. Показано, что трансформация опирается на устойчивое постоянство граждан Республики Крым в их ориентации на Россию, а также на их экономическое поведение, также слабо изменявшееся на протяжении многих лет. В анализе успешности вхождения Крыма в состав России выявлены необходимые для этого условия и их наличие в современном обществе Крыма. Кним относятся достаточность экономических и человеческих ресурсов; гражданское согласие среди элит общества; удержание государством соииального контроля, упреждение острых соииальных конфликтов и вооружённых столкновений. Исследование показало, что у присоединения Крыма к России есть будущее, поскольку современная крымская молодёжь, особенно студенты, твёрдо стоят на «крымских позициях»- учатся и планируют здесь остаться в будущем.
\end{abstract}

Ключевые слова: трансформачия, культурная травма, политический и культурный уклад, крымское общество, местные сообщества, присоединение к России.

Научная специальность: 22.00.00 - социологические науки. 